\title{
ТЕХНІЧНИЙ СТАН БУДІВЕЛЬ РАЙОНУ МОЛДАВАНКА м. ОДЕСИ
}

\section{BUILDINGS' TECHNICAL CONDITION OF THE MOLDAVANKA DISTRICT OF ODESSA}

Чернєва О.С., к.т.н., доцент (Одесская государственная академия строительства и архитектуры), Реутська К.В., бакалавр будівництва

Chernieva O.S., Ph.D. in Engineering, Associate Professor (The Odessa State Academy of Building \& Architecture), Reutska K.V., bachelor

У статті розглянуто проблеми культурної та історичної спадщини району Молдаванка у місті Одеса, проведено аналіз нової та старої забудови. В результаті отриманих даних були зроблені висновки про майбутній стан мікрорайону, а також про можливі перспективи розвитку.

The article is devoted to problems of the Odessa historical center. Moldavanka district has a convenient location to the city center.

The history of the Moldavanka began at the end of the 18th century from a small Moldavian township in the area of the modern Kosvennaya Street and it was recorded on the city plan in 1814. After introduction of the porto franco regime, this region began to settle - after all, the border of the free zone was very close, but Moldavanka did not enter it. The residents of the border's and customs' area received huge profits from smuggling. But in 1826 the border of the porto franko was transferred to the Water hollow and Moldavanka finally became the part of the city. Before the revolution, houses in Moldavanka district were built less quality than in the city center - there was a low-cost housing here. These houses were built with limestone foundations. Naturally, such houses after a hundred or more years are not in the best technical condition.

Currently Moldavanka district is built up with old low-rise buildings. There are many architectural monuments that require full or partial immediate reconstruction. Moldavanka still remains the depressed area of the city. The main cause of depression is an extremely worn out old housing stock, which requires an immediate overhaul, or demolition, 
with the subsequent construction of new houses. Living in emergency houses is not only a deterioration of the life quality, but also a danger for the residents.

The master plan of Odessa provides the quarterly reconstruction of the Moldavanka, in which all buildings of historical and architectural value will be preserved. Other buildings, which condition is good, will also be preserved. Most single-storey and internal buildings, which are in poor technical condition will be demolished. Thus, with the future reconstruction some old houses will remain, the rest of the perimeter is supposed to be low-rise buildings, no more than five floors buildings. In the center of the quarters it is planned to build one higher building than the perimeter buildings. But, unfortunately, the construction of houses in this area is carried out with complete non-compliance with these requirements now. The Moldavanka is densely built up with multi-storey buildings. This leads to permanent accidents of engineering networks and to a traffic collapse. Not to mention the fact that the slopes of this area are also built up in the same way.

Ключові слова: Молдаванка, реконструкція, мікрорайон.

Keywords: Moldavanka, reconstruction, microdistrict.

Район Молдаванка міста Одеси має виключно зручне розташування відносно інших районів міста. В даний час на Молдаванці проживає близько 75-80 тисяч осіб. Має близьке розташування до центру. Саме тому, 3 точки зору логістики в витягнутому на 30 кілометрів уздовж моря місті, проживання на Молдаванці сприятливе для інфраструктури [1]. Проте, Молдаванка як і раніше залишається депресивним районом міста. Основна причина депресивності - вкрай зношений старий житловий фонд, який вимагає або негайного капітального ремонту, або знесення 3 подальшою забудовою новими будинками.

Постає питання про необхідність часткової або повної реконструкції цілого району, а це є дуже складне питання для будьякого міста. За останніми даними, на Молдаванці-2 (так називається ареал перспективної реконструкції району в межах Приморського району) показник зносу аварійних будинків складає 3,75\%, а разом зі старими і зношеними на $60 \%$ і більше. Можна зробити висновок, що до 2031 року, поки буде діяти черговий генплан, їх питома вага значно підвищиться. 
Межі Молдаванки: схід - вул. Старопортофранківська; північ вул. Градоначальницька; захід - вул. Балківська; південь - вул. Заньковецької і генерала Цвєтаєва.

Молдаванка забудовувалася приватними будинками, значна кількість ділянок мали площу 10-12 соток. Периметральна забудова почала складатися тільки до середини XIX століття [2].

Причиною аварійного стану будівель $є$ не тільки вік, a i недотримання домовласників умов експлуатації, та відсутність проведення ремонтних робіт для багатьох будівель 3 метою забезпечення якості житла.

Слід зазначити, що інженерні комунікації, як і тверде покриття доріг та тротуарів, на багатьох вулицях стали з'являтися тільки в 5060-ті роки минулого століття. I на даний час вони потребують ремонту. Отже, фундаменти будинків Молдаванки постійно зволожувалися, а дерев'яні конструкції пошкоджені грибком.

У багатьох місцях точково і цілими кварталами зводилися "сталінки" (на Прохоровскій, Богдана Хмельницького), "хрущовки" (на Запорізькій вулиці) і навіть окремі панельні висотки [2].

Прикладом аварійного будинку $є$ двоповерхова споруда на Ленінградській, 32. Як показано на рис.1 будівлю довелося підпирати опорами, а в проході на подвір'я встановили конструкції, для укріплення верхнього поверху.
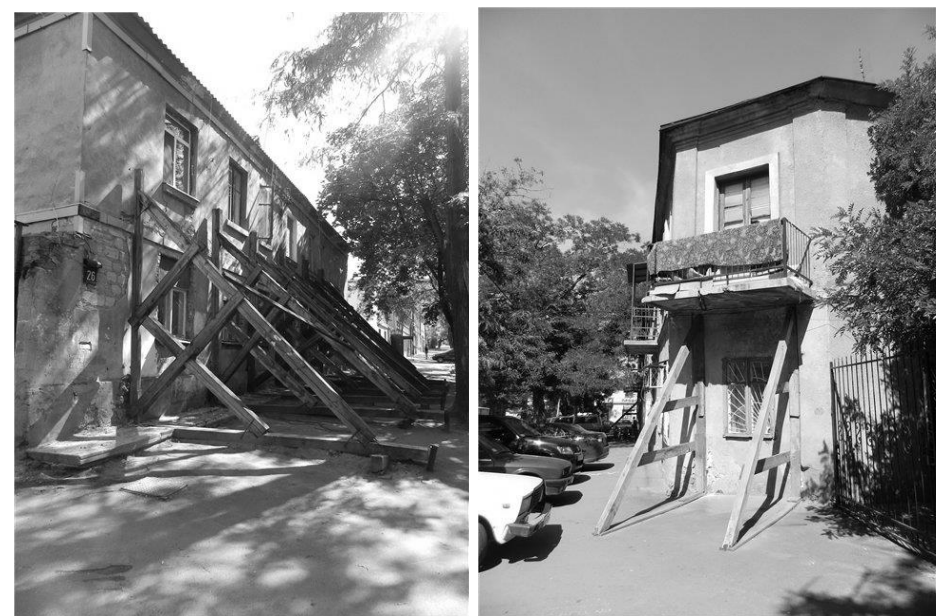

Рис.1. Аварійний стан будинку на Ленінградській, 32 та Розкидайлівській, 26 
На деяких вулицях споруджувались тимчасові укріплення для підтримання стійкості будівель, проте більше не спостерігалось відновлювальних робіт для несучих конструкцій. Так будівля на Розкидайлівській 26 (рис.1) вже більше 10 років потребує капітального ремонту.

Висотне будівництво на Молдаванці почалося із запізненням. Внаслідок цього, питома вага будинків, побудованих ще в середині позаминулого століття, досить значна порівняно 3 новими будівлями. Вік споруд складає 130-170 років. На рубежі століть в центрі міста, особливо між Преображенською i Старопортофранківською вулицями, відбувалася масова заміна невеликих будинків на 3-х...5-и поверхові. Кількість нових будинків, надбудов, флігелів в окремі роки доходила до 300-400 штук. Капітальне будівництво велося нерівномірно.

На початку XXI століття на Молдаванці-2 з'явився цілісний район нової забудови вздовж вулиці Ніщинського (рис.2). Проте більша частина старих будинків знаходиться зараз в критичному стані, непридатному для нормальної експлуатації.

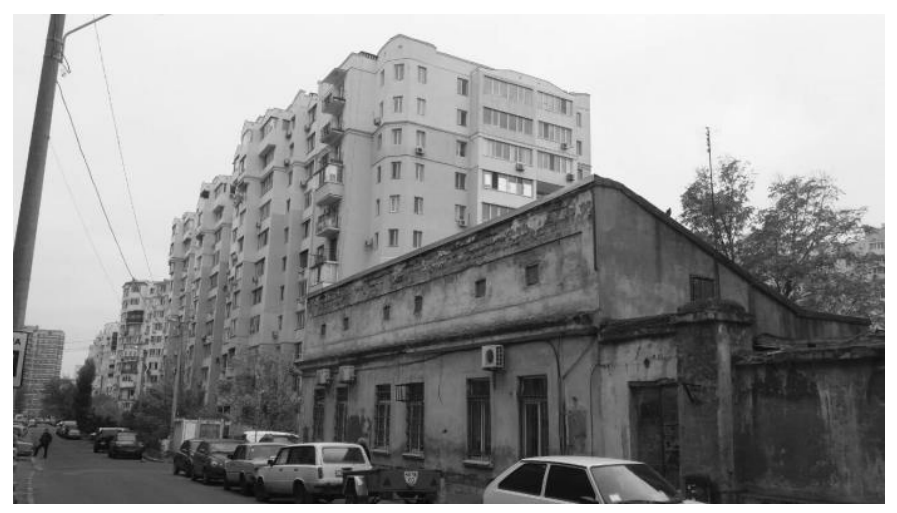

Рис.2. Нова та стара забудова по вулиці Ніщинського

Особливу небезпеку представляють руйнування карнизів старих будинків. Як бачимо (рис. 3) карниз будинку по вулиці Сєрова 37 являє собою небезпеку. Це пам'ятник архітектури та, свого часу, досить престижний прибутковий будинок. Вік експлуатації становить 120 років. 


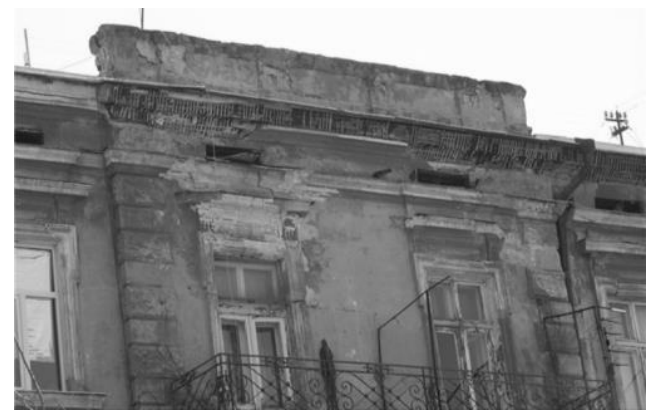

Рис.3. Карниз будинку по вулиці Серова 37

Крім того, більшість мереж водопроводу, каналізації, електромережі - побудовані кілька десятків років тому не відповідають нормативним навантаженням.

Внаслідок недодержання правил технічної експлуатації, та не проведення ремонтних робіт все частіше відбуваються нещасні випадки с мешканцями старих будинків. 7 листопада 2018 року обрушився балкон третього поверху будинку на перехресті вулиць Буніна і Канатній (рис.4). Постраждалий спочатку впав на дах розташованого під будинком кафе, проломив іiі i провалився всередину [3].
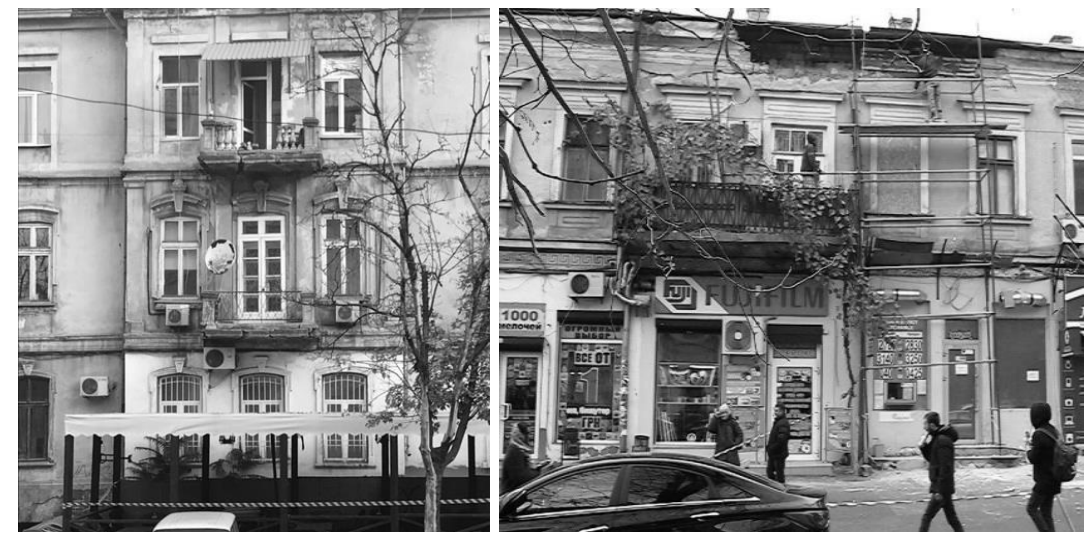

Рис.4. Обвалення балкону на перехресті вулиць Буніна i Канатна та ремонтні заходи старого будинку на розі Садової і Торгової вулиць 
11 листопада 2018 року на розі Садової і Торгової вулиць, де проводиться реконструкція старого будинку, на голову перехожому впала цеглина (рис.4). На місці події можна побачити, що рештування стоять не під балконом, а під величезною дірою під дахом, яка утворилася у вересні поточного року. Звідси, швидше за все, і впав камінь. Робочі закладають діру цегляною кладкою [4].

Такі випадки відбуваються все частіше і несуть небезпеку для жителів міста. Важливо проводити не тільки своєчасний ремонт, але й дотримуватись правил техніки безпеки та робити заходи для запобігання нещасних випадків.

Проаналізувавши майбутнє мікрорайону на найближчі пару десятків років можна зробити висновок про те, що не почавши реконструкцію зараз, це призведе до експлуатаційного колапсу. Забудова і реконструкція Молдаванки в поквартальному виконанні може бути цікава інвестору тільки за умови, що старих будинків в кварталі залишиться незначна кількість - інакше основні кошти доведеться вкладати не в нове будівництво, а в реконструкцію старих будівель. Однією 3 переваг реконструкції Молдаванки, 3 точки зору інвестора, можна назвати тільки - близькість до історичного центру міста.

Основні лінії електропередач, водопроводу i каналізації прокладалися в 30-е і 50-е роки і до революції. Вони не розраховані на різке збільшення навантаження, яке відбудеться при новому будівництві. Тому Молдаванка потребує капітальної заміни інженерних мереж, причому зі збільшенням їх пропускної здатності як мінімум удвічі. Причому, побудовані багатоповерхові будівлі вже збільшили навантаження на старі мережі.

Одним 3 проблемних факторів $є$ катакомби. Частина може впасти, ще частина затоплена, інші ще не досліджені. Наявність катакомб веде до подорожчання будівництва за рахунок досліджень та необхідності підсилень підземних виробок. Протікаючі труби водопроводу i каналізації сприяють просіданню грунту, а потрапляння води в катакомби погрожує обваленням останніх.

В даний час процес забудови Молдаванки новими будинками йде зовсім іншим шляхом. «Девелопери» освоюють території занедбаних складів, автобаз та заводів між Балківською і Степовою, зводячи тут цілі квартали багатоповерхівок. Все це будується на катакомбах, на схилі Водяної балки, але це не вимагає здороження 
будівництва через необхідність розселення жителів старих будинків.

Запланована в Генплані поквартальна реконструкція району, 3 одного боку, дасть можливість поступово замінити інженерні мережі в процесі будівельних робіт в масштабах цілої вулиці або кварталу. 3 іншого - при послідовному ході робіт до закінчення терміну Генплану в 2031 року навряд чи вийде оновити більше, ніж 3-4 квартали. Одночасна реконструкція відразу декількох кварталів місту не під силу навіть при наявності дуже багатих інвесторів просто не вистачить житла для тих, кого відселяють з будинків, що реконструюються.

Висновки. Прогнози щодо майбутнього Молдаванки:

1. Якщо знайдеться коректний інвестор, почнеться послідовна квартальна реконструкція. Протягом кількох десятиліть, які буде діяти нинішній генплан, таким чином спільними зусиллями міста та інвесторів вдасться реконструювати два-три квартали. Решта ж кварталів Молдаванки будуть надані самі собі - залишаться незмінними, або піддадуться хаотичній забудові. Відповідно, в кварталах, що залишилися без реконструкції, рано чи пізно настане колапс інженерних мереж.

2. У зовсім негативному варіанті такого інвестора не буде. Місто своїми силами не могло, не може і не зможе протягом кількох десятиліть капітально перебудувати хоча б третину Молдаванки. Тому район, як і зараз, буде піддаватися точкової забудови 3 вищеописаною небезпекою повного зносу комунікацій. Адже забудовники при такому сценарії лише зводять висотки і платять в бюджет на розвиток міської інфраструктури незначні кошти порівняно з одержуваними ними прибутками.

\section{Список використаних джерел}

1. http: // reporter.com.ua / articles /f7v/ 2. https: //uc.od.ua /news/ urbanism / 1187387 3. https: // korrespondent.net/city/odessa/4030237 - v odesse - obrushylsia - balkon - vmeste - s - khoziaynom 4. http: // dumskaya.net/news/ v - tcentre - odessy - vo - vremya - restavratcii - fasada $\mathrm{k}-092179$ / 